\title{
Editorial
}

William Addis MA (Cantab), PhD, MCIOB

Consulting Engineer, Buro Happold, London, UK

Many different words are used to describe what engineers and architects do when working on existing structures and buildings, whether of great heritage importance or not conservation, restoration, rehabilitation, refurbishment, renovation and repair, to name just six. There is much debate about what they all mean and, indeed, whether it really matters exactly what they mean - and this is surely a good theme for a briefing article in a future issue of Engineering History and Heritage.

In recent years another word has increasingly been applied to these various activities - sustainable or sustainability. Suddenly, it would appear, a new reason for looking after existing structures and buildings is that this is 'more sustainable' - more sustainable, presumably, than demolition and replacement. So, does this relatively new word add anything to our understanding of what to do with existing structures and buildings? I would suggest not, but that is not to say that the word needs to be ignored or banned.

The commission chaired by Gro Harlem Brundtland defined sustainable development in 1987 as, "development which meets the needs of current generations without compromising the ability of future generations to meet their own needs" (WCED, 1987: p. 43). Although the commission had originally been formed to address environmental and development issues, it quickly came to see that these issues are entwined with many others and the final report was called Our Common Future (WCED, 1987). Since that time the idea of sustainable development has been widely seen as embracing social (cultural), economic and environmental issues and is agreed to include the built environment as well as the natural environment.

Any definition of a society's culture must embrace its history and the remaining legacy of that history. To neglect this legacy is to erode the very bedrock of cultural identity - that which distinguishes linguistic groups, geographical regions, economic systems and political nations. The construction of our built environment and the resources needed to operate it consume more non-renewable natural resources than any other human activity. Whether looking at existing structures or new ones, we must clearly be as sparing as possible in our use of these resources and ensure that the environmental impact of the full range of construction-related activities is minimised to ensure we are not "compromising the ability of future generations to meet their own needs".
Care for our engineering history and heritage is thus central to two (cultural, environmental) of the three cornerstones of sustainable development. It will be of great benefit to mankind and our planet to ensure that the engineers see their work on preserving and extending the useful life of existing engineering and building structures, whether of so-called 'heritage' significance or not, as of more than merely technical or economic benefit.

Engineers have often been, and can still be, specialists happy to carry on their lives within enclosed walls. The idea of 'sustainability' has brought to the work of engineers, especially those working with existing structures, a framework into which all aspects of their work can be collected and treated in a holistic way, and which enables their contribution to the holistic picture to be more clearly visible. At the very least, this can help engineers to see the wider value to their work and, hopefully, to enable others to see the value of the engineers' contribution.

\section{Papers in this issue}

In the first paper, 'Preserving canals through innovating maintenance spot dredging', Claire Greenwood (2014) describes a new approach to maintaining canals in which dredging techniques developed for coastal work are adapted for use in canals. This enables the process to be completed much more quickly, up to twice as quick, than using conventional techniques. This will surely be good news for those organisations responsible for maintenance of canals.

Just as canals need regular dredging, so do lock gates need regular maintenance and eventual replacement. Michael Clarke gives an excellent introduction to the development of lock gates in his paper 'The history and replacement of lock gates' (Clarke, 2014). As with most civil engineering structures, the keys to their successful maintenance and replacement are to understand the origins of their original construction and to have a full knowledge of the materials and construction methods used. As with many historic structures from previous centuries, original drawings and design calculations are at best rare, and modern restoration requires a detailed survey of the structure as built, followed by a careful assessment of how it was constructed and how it carried its intended loads. Only in this way can they be effectively and sensitively repaired or restored.

Jeremy Foster describes the restoration of an unusual historic monument - the heritage listed clock tower in Woolwich 
Arsenal in London (Foster, 2014). The structure collapsed when an unauthorised piece of construction plant accidentally impacted on a temporary support, dislodging an essential load-bearing element of the building. The resulting work required a painstaking process of salvaging and reconstructing the structure using as much of the original as possible. The fascinating story involved a wide variety of assessment and restoration techniques and is a model case study for this type of work.

A popular view of progress in engineering is that ever more daring structures are built until one fails, thus determining the limit to a certain technology - a process of trial and error. In fact, relatively few structures, even in the nineteenth century, failed. And when they did, it was often due to poor construction or poor quality or poorly understood (unfamiliar) materials such as cast iron or riveted wrought iron. Nicholas Bill (2014) summarises the safety record of a small but significant group of railway structures - those made of timber. In fact they were remarkably successful, perhaps because the material was more familiar than iron. The results of his study are important to anyone faced with restoring such bridges their particular safety record needs to be understood, especially how different it was from iron structures.

The final paper, by Gwylm Roberts (2014), is a short biography of Frederick Cooper, an extraordinary engineer who had a major hand in four of the most remarkable engineering marvels of the nineteenth century - the southern section of London's Circle Line (part of the London Underground), the Forth rail bridge, while working for the contractors Arrol, a tunnelled section of the Central Line on London's underground and, most publicly perhaps, the transportation of Cleopatra's Needle from Egypt to London.

\section{REFERENCES}

Bill N (2014) The safety record of timber railway bridges in the UK: 1840-1870. Proceedings of the Institution of Civil Engineers - Engineering History and Heritage 167(1): 34 46, http://dx.doi.org/10.1680/ehah.13.00015.

Clarke M (2014) The history and replacement of lock gates. Proceedings of the Institution of Civil Engineers Engineering History and Heritage 167(1): 10-21, http://dx. doi.org/10.1680/ehah.13.00012.

Foster JV (2014) Rebuilding Woolwich Arsenal clock tower, London, UK. Proceedings of the Institution of Civil Engineers - Engineering History and Heritage 167(1): 2233, http://dx.doi.org/10.1680/ehah.13.00017.

Greenwood CL (2014) Preserving canals through innovating maintenance spot dredging. Proceedings of the Institution of Civil Engineers - Engineering History and Heritage 167(1): 4-9, http://dx.doi.org/10.1680/ehah.13.00013.

Roberts G (2014) Frederick Cooper (1841-1933): the supreme resident engineer. Proceedings of the Institution of Civil
Engineers - Engineering History and Heritage 167(1): 47-

60, http://dx.doi.org/10.1680/ehah.13.00011.

WCED (World Commission on Economic Development) (1987) Our

Common Future. Oxford University Press, Oxford, UK.

\section{PAPERS ELSEWHERE IN THE ICE PROCEEDINGS}

A regular challenge to placing papers of engineering history and heritage interest is whether they should appear in the subject journals, devoted, say, to bridges or ground engineering, or whether they should be published in this journal. The answer is, they may appear in either and so it is worth bring to our readers' attention the following papers that were published in other ICE Proceedings journals during 2013.

\section{BRIDGE ENGINEERING}

Amir-Ansari S (2013) Design and construction of bridges in Fiji. Proceedings of the Institution of Civil Engineers - Bridge Engineering 166(2): 95-103, http://dx.doi.org/10.1680/bren. 12.00011

Donald PTA (2013) Building bridges from the Foyle to Ojague. Proceedings of the Institution of Civil Engineers - Bridge Engineering 166(2): 76-82, http://dx.doi.org/10.1680/bren. 11.00043

Harvey B (2013) A spatial view of the flow of force in masonry bridges. Proceedings of the Institution of Civil Engineers Bridge Engineering 166(1): 36-50, http://dx.doi.org/10.1680/ bren.10.00007.

Ho LH (2013) Lifecycle management of footbridges: a framework. Proceedings of the Institution of Civil Engineers Bridge Engineering 166(4): 252-261, http://dx.doi.org/10. 1680/bren.11.00004.

Liu X, Macdonald JHG and Chen W (2013) Kinetic analysis and rehabilitation of old bascule bridge in Tianjin, China. Proceedings of the Institution of Civil Engineers - Bridge Engineering 166(1): 36-50, http://dx.doi.org/10.1680/bren. 10.00007.

Pakrashi V, Harkin J, Kelly J, Farrell A and Nanukuttan S (2013) Monitoring and repair of an impact damaged prestressed bridge. Proceedings of the Institution of Civil Engineers Bridge Engineering 166(1): 16-29, http://dx.doi.org/10.1680/ bren.10.00057.

Thiebault V, Du G and Karoumi R (2013) Design of railway bridges considering life-cycle assessment. Proceedings of the Institution of Civil Engineers - Bridge Engineering 166(4): 240-251, http://dx.doi.org/10.1680/bren.10.00054.

\section{CIVIL ENGINEERING}

Basu NB, Dey A and Ghosh D (2013) Kolkata's brick sewer renewal: history, challenges and benefits. Proceedings of the Institution of Civil Engineers - Civil Engineering 166(2): 74 81, http://dx.doi.org/10.1680/cien.12.00016.

Bessant G and McKoy R (2013) London Underground: unravelling 150 years of structural secrets. Proceedings of 
the Institution of Civil Engineers - Civil Engineering 166(1): 27-34, http://dx.doi.org/10.1680/cien.12.00006.

Franco M (2013) São Paulo building for the future freezeframes Brazil's past. Proceedings of the Institution of Civil Engineers - Civil Engineering 166(6): 13-19, http://dx.doi. org/10.1680/cien.13.00027.

Marney R (2013) Institution of Civil Engineers launches online image library. Proceedings of the Institution of Civil Engineers - Civil Engineering 166(4): 150, http://dx.doi.org/ 10.1680/cien.2013.166.4.150.

Sims I (2013) Natural stone: sustaining the future of the world's oldest construction material. Proceedings of the Institution of Civil Engineers - Civil Engineering 166(4): 149, http://dx. doi.org/10.1680/cien.2013.166.4.149.

\section{CONSTRUCTION MATERIALS}

de Llorens Duran JI (2013) Wine cathedrals: making the most of masonry. Proceedings of the Institution of Civil Engineers Construction Materials 166(6): 329-342, http://dx.doi.org/ 10.1680/coma.12.00023.

Sims (2013) Book review: The History of Stainless Steel. Proceedings of the Institution of Civil Engineers Construction Materials 166(1): 57, http://dx.doi.org/10. 1680/coma.11.00066.

Walker P (2013) Book review: Building Scotland: Celebrating Scotland's Traditional Building Materials. Proceedings of the Institution of Civil Engineers - Construction Materials 166(5): 326, http://dx.doi.org/10.1680/coma.12.00012.

\section{ENGINEERING SUSTAINABILITY}

McGrath T, Nanukuttan S, Owens K, Basheer M and Keig P (2013) Retrofit versus new-build house using life-cycle assessment. Proceedings of the Institution of Civil Engineers Engineering Sustainability 166(3): 122-137, http://dx.doi. org/10.1680/ensu.11.00026.

\section{FORENSIC ENGINEERING}

Benn J (2013) Railway bridge failure during flooding in the UK and Ireland. Proceedings of the Institution of Civil Engineers Forensic Engineering 166(4): 163-170, http://dx.doi.org/10. 1680/feng.2013.166.4.163.

Clark GM (2013) Post-tensioned structures - improved standards. Proceedings of the Institution of Civil Engineers Forensic Engineering 166(4): 171-179, http://dx.doi.org/10. 1680/feng.13.00010.

Ingham J and McKibbins L (2013) Concrete structures affected by cracking. Proceedings of the Institution of Civil Engineers Forensic Engineering 166(1): 3-8, http://dx.doi.org/10.1680/ feng.12.00018.
Lazarus D (2013) Water, water everywhere: ingress in underground structures. Proceedings of the Institution of Civil Engineers - Forensic Engineering 166(4): 189-197, http://dx.doi.org/10.1680/feng.13.00011.

Rawska-Skotniczny A, Zmuda J and Jankowiak R (2013) Potential collapse of a roof structure averted by quick repair. Proceedings of the Institution of Civil Engineers - Forensic Engineering 166(4): 157-162, http://dx.doi.org/10.1680/ feng.2013.166.4.157.

Searls CL and Stubblefield TN (2013) Investigation of large-scale building envelope leakage. Proceedings of the Institution of Civil Engineers - Forensic Engineering 166(1): 27-40, http:// dx.doi.org/10.1680/feng.12.00004.

\section{MUNICIPAL ENGINEER}

Basu NB, Boral S, Mandal SK and Dey A (2013) Rehabilitation of Kolkata's first Victorian-age brick sewer. Proceedings of the Institution of Civil Engineers - Municipal Engineer 166(4): 230-238, http://dx.doi.org/10.1680/muen.12.00051.

\section{STRUCTURES AND BUILDINGS}

Che A, Ge X and Li Y (2013) Use of non-destructive techniques in Chinese traditional timber structures. Proceedings of the Institution of Civil Engineers - Structures and Buildings 166(6): 307-315, http://dx.doi.org/10.1680/stbu.10.00019.

Ebbert T (2013) Integrated refurbishment planning for sustainable office buildings. Proceedings of the Institution of Civil Engineers - Structures and Buildings 166(2): 100-107, http://dx.doi.org/10.1680/stbu.10.00062.

Everett CP (2013) Sheffield Arts Tower: rejuvenation of a II* listed structure. Proceedings of the Institution of Civil Engineers - Structures and Buildings 166(1): 38-48, http:// dx.doi.org/10.1680/stbu.10.00072.

Pape TM and Melchers RE (2013) Performance of 45-year-old corroded prestressed concrete beams. Proceedings of the Institution of Civil Engineers - Structures and Buildings 166(10): 547-559, http://dx.doi.org/10.1680/stbu.11.00016.

Thew I, Sutherland A and Theodossopoulos D (2013) Structural response of drystone Iron Age brochs. Proceedings of the Institution of Civil Engineers - Structures and Buildings 166(6): 316-324, http://dx.doi.org/10.1680/stbu.11.00056.

\section{WATER MANAGEMENT}

Donaldson M (2013) Rehabilitation and modernisation of irrigation schemes. Proceedings of the Institution of Civil Engineers - Water Management 166(5): 242-253, http://dx. doi.org/10.1680/wama.12.00054. 